\title{
THE IMPACT OF THE BAN ON SPENDING WEEKLY REST IN THE VEHICLE ON TRANSPORT PLANNING IN THE EU
}

DOI 10.2478/ntpe-2018-0003

\author{
doc. Ing. Miloš Poliak, PhD. \\ Ing. Patrícia Šimurková \\ University of Zilina, Slovak Republic \\ dr hab. inż. Marek Jaśkiewicz, prof. PSk \\ Kielce University of Technology, Poland \\ mgr inż. P. Posuniak \\ Automotive Industry Institute (PIMOT), Poland \\ dr inż. J. Stokłosa \\ University of Economics \\ and Innovation in Lublin, Poland
}

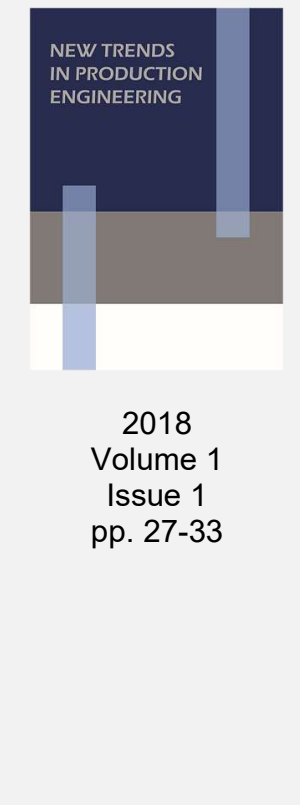

\begin{abstract}
The working conditions of truck drivers and social legislation are both topical and political issues in the field of road freight transport. The contribution outlines problems which are linked to the observance of the ban on weekly rest in the vehicle. Based on the judgment, the Court of Justice of the European Union explicitly forbids drivers to take their regular weekly rest in the vehicle. The contribution identifies the impact of the ban on spending weekly rest in the vehicle on transport planning in the EU. The aim of the contribution is also to highlight the existing problems in international road freight transport sector in connection with insufficient number of truck parks with accommodation.
\end{abstract}

Keywords: road freight transport, weekly rest, driver, vehicle, truck parking

\section{INTRODUCTION}

Market access is balanced by EU-wide rules in the fields of driving and rest times in road freight transport and social equality under conditions that ensure a fair and open competitive environment. As the driver's profession in road transport is very demanding, the rules governing work and rest time are strict. The working conditions of truck drivers, social legislation and market protection are both topical and political issues in the field of road freight transport (Lubanski, 2000). Of all the road freight transport legislation, the social legislation, which is one of the most important legal areas for road haulers, but also for drivers, plays a significant role and whose changes have a considerable impact on the transport planning. Proper compliance with social legislation in road transport, such as observance of the ban on weekly rest in the vehicle, ensures for individual transport companies and especially drivers not only the certainty that they will not be subject to sanctions by the control authorities but their main aim is to prevent accidents due to lack of concentration or driver fatigue (CEMT, 2002).

\section{SOCIAL LAW IN ROAD TRANSPORT GOVERNING CONDITIONS OF WEEKLY REST IN THE EU}

The driver working regime within the EU (including Switzerland, Norway, Liechtenstein and Iceland) is regulated by Regulation (EC) No. 561/2006 laying down rules on driving times, breaks and rest periods for drivers engaged in road and passenger transport.

According to Regulation (EC) No. 561/2006, the driver is obliged to draw regular daily and weekly rest. The weekly rest period is a time period of one week during which the driver may freely dispose of his time and includes a period of:

- regular weekly rest - any rest period of at least 45 hours, 
- reduced weekly rest period - any rest period of less than 45 hours, which may be shortened to at least 24 consecutive hours.

The weekly rest period begins no later than at the end of the six-week period of 24 hours from the end of the previous weekly rest period. This means that the new weekly rest period must be started at the latest 144 hours after the end of the previous weekly rest period (Poliak and Gnap, 2015).

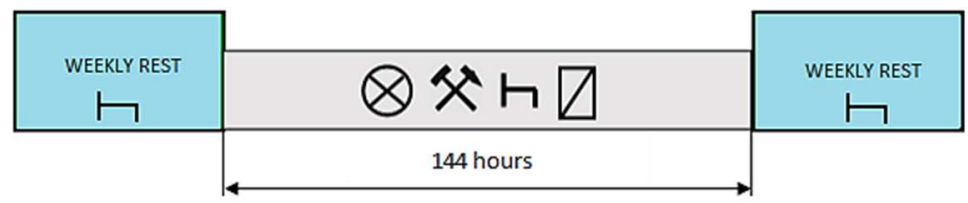

Fig. 1. Drawing on weekly rest under the Regulation No. 561/2006

Regulation No. 561/2006 also provides that the driver draws at least two consecutive weeks:

- two regular weekly rest periods or

- one regular weekly rest period and one reduced weekly rest period of at least 24 hours. However, this shortening will be replaced by a reasonable breakdown drawn in full before the end of the third week following that week.

Any rest taken to compensate for the reduced weekly rest period shall be added to a further rest period of at least nine hours. This means that it is not possible to take a reduced weekly rest period for two weeks.

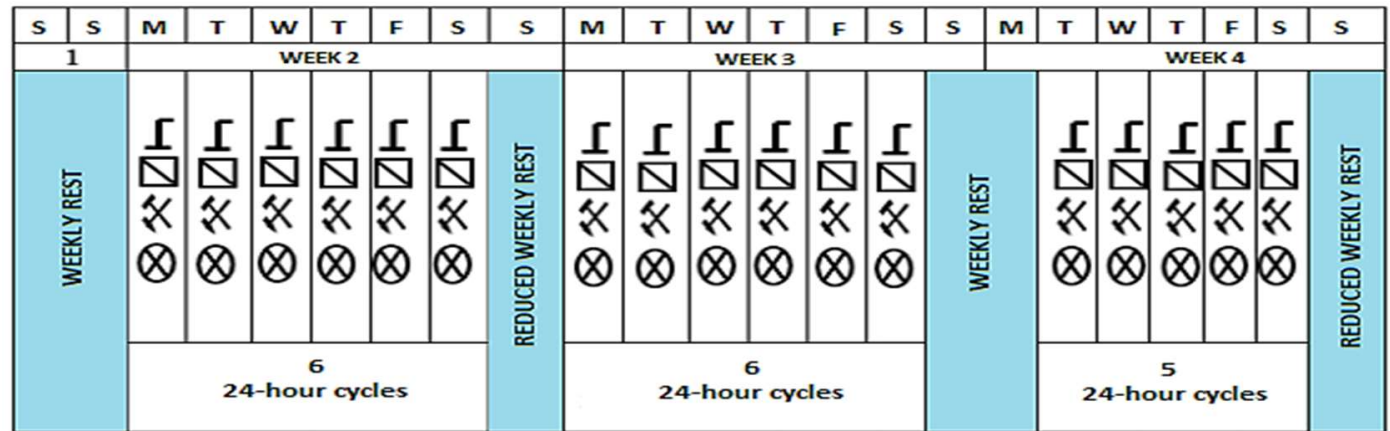

Fig. 2. Proper use of the rule to attach weekly rest periods to one week or the other

The daily rest period on the last working day of a week may be extended to a regular weekly rest period or a reduced weekly rest period. That is, in each week one of the daily rest periods must be extended and used as a weekly rest period. Weekly rest periods, starting in one week and continuing to the next week, may be linked to one or the other of these weeks, but not to both (Poliak and Gnap, 2015).

\section{The ban on spending weekly rest in the vehicle}

According to Art. 8 Regulation No. 561/2006, the driver can take daily rest and reduced weekly rest in the vehicle if the vehicle is fitted with suitable sleeping facilities for each driver and the vehicle is stationary. In practice, however, this condition did not generally apply until 2014. In the summer of 2014, Belgium and France adjusted the scale of fines according to which a fine is imposed on the driver for taking a regular weekly rest, namely up to $€ 1,800$ in Belgium and from 11 July 2014 up to $€ 30,000$ or imprisonment for one year in France (Poliak and Poliaková, 2015).

The Court of Justice of the European Union, in its judgment of 20 December 2017, also took a stand on the issue of regular weekly rest. In the judgment, the court ruled that truck drivers cannot spend a regular weekly rest in vehicles. This means that no EU country can interpret legislation in a different way (Ayala et al., 2010). The dragging litigation began three years ago when the Belgian transport company Vaditrans BVBA started a litigation with the Kingdom of Belgium. The haulier believed that it was not possible to fine the regular weekly rest because 
Regulation (EC) 561/2006 does not provide for such a ban. Regulation (EC) No. Article 8 (8) of Regulation (EC) No 561/2006 states: "Where a driver chooses to do this, daily rest periods and reduced weekly rest periods away from base may be taken in a vehicle, as long as it has suitable sleeping facilities for each driver and the vehicle is stationary". The Belgian authorities also referred to the wording of the cited Regulation (EC) No. (EC) No 561/2006 and requested clarification as to whether that provision of Regulation (EC) Of Regulation No 561/2006 is to be interpreted as containing an implicit prohibition of the use of regular weekly rest periods in a vehicle.

As EU law can only be enforced by the EU Court, the Belgian court then asked the EU court to determine whether the EU law contained an implicit ban on taking a standard weekly rest in a vehicle (Newman and Kenworthy, 1999), (Rotondo, 2013). The EU Court said that EU law refers only to the possibility of reducing the weekly rest period by 24 hours, which is permitted in some circumstances in the vehicle, so this means that it should not apply to a regular 45hour rest. If allowed, then the driver could spend all the rest in the vehicle, which would not improve drivers' working conditions as intended by EU law.

Based on the judgment, the Court of Justice of the European Union explicitly forbids drivers to take their regular weekly rest in the vehicle. The judgment is effective from the date of publication, that is, from 20 December 2017. It is also necessary to state that the judgment is valid in all EU Member States, that is to say, if national law permits a fine to be imposed on such a offense, the control body may impose the fine (Domonkos et al., 2017). The judgment does not regulate the power to control the use of taking regular weekly rest only on the territory of a particular State. The judgment provides that regular weekly rest cannot be taken by drivers in the vehicle. This means that, for example, in Belgium, the control authorities find that a Slovak driver who runs a vehicle of a carrier based in Slovakia has a regular weekly rest in Germany, he can take a restraint fine in Germany at check in Belgium. It should be noted that the place of regular weekly rest can be found in the previous 28 days of the digital tachograph or the driver card. Therefore, the drivers, when entering the country of arrival and country of exit on a digital tachograph, should be consistent and set the country code consistently (Poliak, 2007).

On the other site, it should be noted that the amount of the fines is set by the national law of the individual EU Member States and will take some time if the fine for regular weekly rest in the vehicle is added to the national regulations of all countries. Regulation (EU) 2016/403, which has updated the classification of serious EU road traffic offenses since 1 January 2017, does not include a violation of the rules: regular driver's weekly rest on the vehicle. According to this classification, individual Member States have adopted a national law setting fines in the field of road transport.

\section{TRANSPORT PLANNING IN THE EU IN RELATION TO TAKING WEEKLY REST OUTSIDE THE VEHICLE}

The ban on weekly rest periods points to a number of other problems which are linked to the Court's judgment. Trucks must park at specified truck parks, usually out of town, which often do not have motels or hotels nearby (Drozdziel and Piasecki 1995). In connection with this problem, three routes of transport leading from the Slovak Republic to selected EU countries were processed and subsequently truck parks were found which provide the driver with the possibility of accommodation in case of taking regular weekly rest. Truck parks were searched by application Truck Parking Europe, which shows the appropriate parking options on a given route with a maximum detour of $12 \mathrm{~km}$. Following the search for individual truck parks and their accommodation facilities, the accommodation capacity was also surveyed, but in some cases this information was not available. Based on individual capacities, accommodations can be divided into three categories according to the number of rooms as follows:

- small (1 to 20 rooms),

- medium (21 to 40 rooms),

- large (more than 40 rooms). 
In Fig. 3 shows the first route leading from Slovakia (Žilina) to France (Lyon) with a total length of $1449 \mathrm{~km}$, while there are 201 truck parks or rest areas available but the possibility of accommodation satisfies only 16 truck parks. Of the truck parks they provide on a given route for driver accommodation, $50 \%$ is located in Switzerland. The other example is the Slovak Republic, where no such truck parks was found on the chosen route after the evaluation via the application. Table 1 also indicates the capacity of the accommodation, with most of which can be classified in the middle category (21-40 rooms). Capacity of more than 40 rooms meet only 4 accommodation facilities out of 13 people found.

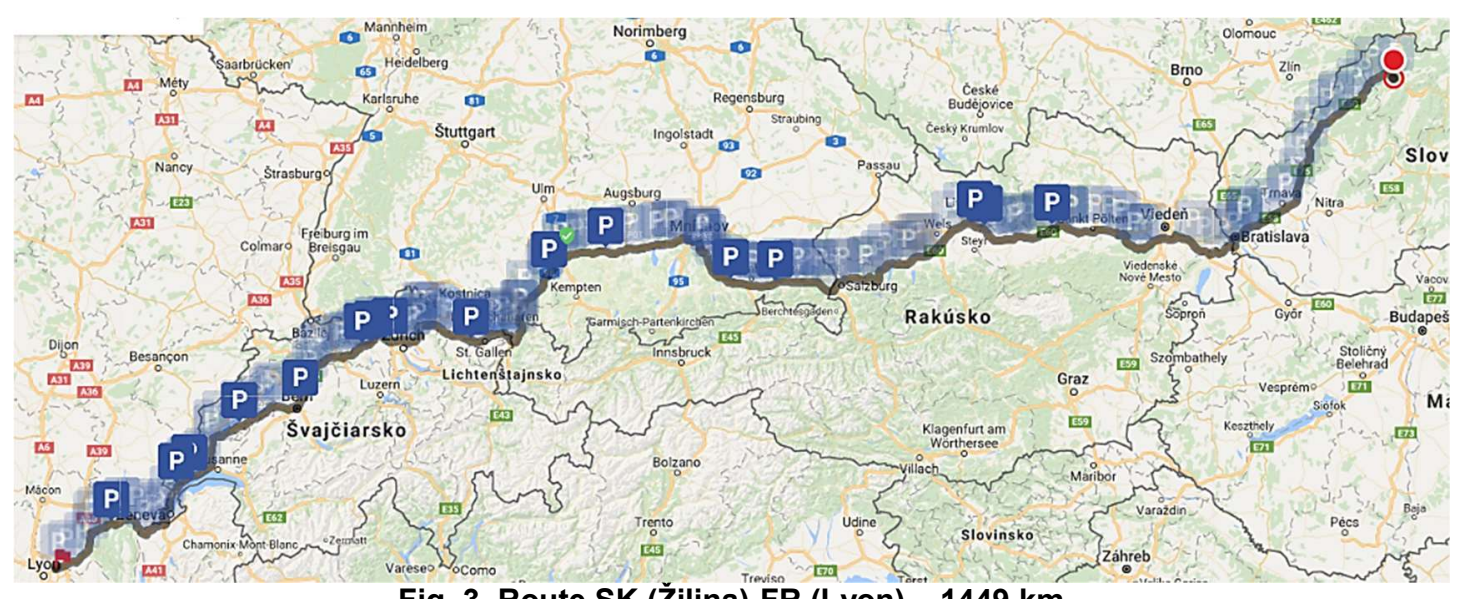

Fig. 3. Route SK (Žilina)-FR (Lyon) - 1449 km

Table 1

Possibilities of regular weekly rest on the route Žilina (SK)-Lyon (FR)

\begin{tabular}{|c|c|c|c|c|}
\hline Number & $\begin{array}{l}\text { Parking for trucks } \\
\text { with accommodation }\end{array}$ & Country & Accommodation & $\begin{array}{l}\text { Accommodation } \\
\text { capacity }\end{array}$ \\
\hline 1. & $\begin{array}{l}\text { Gasthaus Gramel, } 3380 \text { Oostenrijk } \\
\text { (Anton Schlecker Str. 1, } 3380 \text { Pöchlarn }\end{array}$ & AT & Gasthaus Gramel & $\begin{array}{l}21 \text { rooms } \\
\text { (44 beds) }\end{array}$ \\
\hline 2. & $\begin{array}{l}\text { Landzeit Sankt Valentin, Rasthausstraße } 6 \text {, } \\
4300 \text { St. Valentin }\end{array}$ & AT & $\begin{array}{l}\text { Motor-Hotel } \\
\text { Sankt Valentin }\end{array}$ & $\begin{array}{l}30 \text { rooms } \\
\text { (60 beds) }\end{array}$ \\
\hline 3. & $\begin{array}{l}\text { Gasthaus Heimbau Einsiedlstraße 28, } \\
4481 \text { Asten }\end{array}$ & AT & Gasthaus Heimbau & not indicated \\
\hline 4. & $\begin{array}{l}\text { Theodor-Sanne-Straße 3, Bernau Am } \\
\text { Chiemsee }\end{array}$ & DE & $\begin{array}{l}\text { Camping } \\
\text { Mariengrund }\end{array}$ & $\begin{array}{l}6 \text { rooms } \\
\text { (18 beds) }\end{array}$ \\
\hline 5. & $\begin{array}{l}\text { Rasthof Irschenberg Süd, Wendling 12, } \\
83737 \text { Irschenberg }\end{array}$ & DE & $\begin{array}{l}\text { Autobahnmotel } \\
\text { Irschenberg Süd }\end{array}$ & $\begin{array}{l}50 \text { rooms } \\
\text { (114 beds) }\end{array}$ \\
\hline 6. & Mindelheimer Str. 2, 86842 Türkheim & $\mathrm{DE}$ & Landhaus Rosenbräu & not indicated \\
\hline 7. & $\begin{array}{l}\text { Euro Rastpark Aichstetten, Am Waizenhof } \\
12,88317 \text { Aichstetten }\end{array}$ & DE & Al Hotel & $\begin{array}{l}21 \text { rooms } \\
\text { (44 beds) }\end{array}$ \\
\hline 8. & Wilerstrasse 46, 9200 Gossau & $\mathrm{CH}$ & $\begin{array}{l}\text { Hotel Gasthaus } \\
\text { Moosburg }\end{array}$ & 40 beds \\
\hline 9. & $\begin{array}{l}\text { Hotel Geroldswil, Huebwiesenstrasse 36, } \\
8954 \text { Geroldswil }\end{array}$ & $\mathrm{CH}$ & Hotel Geroldswil & $\begin{array}{l}71 \text { rooms } \\
\text { (134 beds) }\end{array}$ \\
\hline 10. & $\begin{array}{l}\text { Landgasthof Pflug, Lenzburgerstrasse } 4 \text {, } \\
5504 \text { Othmarsingen }\end{array}$ & $\mathrm{CH}$ & Landgasthof Pflug & not indicated \\
\hline 11. & $\begin{array}{l}\text { Gasthof Kastanienbaum, Hauptstrasse 19, } \\
\mathrm{CH}-5502 \text { Hunzenschwil }\end{array}$ & $\mathrm{CH}$ & $\begin{array}{l}\text { Gasthof } \\
\text { Kastanienbaum }\end{array}$ & $\begin{array}{l}15 \text { rooms } \\
\text { ( } 26 \text { beds) }\end{array}$ \\
\hline 12. & $\begin{array}{l}\text { Raststätte Grauholz Nord, Wolfackerweg } \\
18,3063 \text { Ittigen }\end{array}$ & $\mathrm{CH}$ & $\begin{array}{l}\text { Raststätte Grauholz } \\
\text { Nord }\end{array}$ & 62 rooms \\
\hline 13. & $\begin{array}{l}\text { Rose de La Broye, Autogrill Schweiz AG } \\
\text { Restoroute Rose de, } 1470 \text { Lully }\end{array}$ & $\mathrm{CH}$ & $\begin{array}{l}\text { Park Inn by Radisson } \\
\text { Lully }\end{array}$ & 80 rooms \\
\hline 14. & Place de La Gare 2-3, Rolle & $\mathrm{CH}$ & Loft de charme & $\begin{array}{l}1 \text { room } \\
\text { (3 beds) }\end{array}$ \\
\hline 15. & $\begin{array}{l}\text { Hotel-Restaurant Le Petit Moulin, } \\
\text { Route Blanche 1, } 1274 \text { Grens }\end{array}$ & $\mathrm{CH}$ & $\begin{array}{l}\text { Hotel-Restaurant } \\
\text { Le Petit Moulin }\end{array}$ & 22 rooms \\
\hline 16. & $\begin{array}{l}\text { Hotel Restaurnat Le Relax, } \\
\text { Rue du Clou } 138 \text { Maillat }\end{array}$ & FR & $\begin{array}{l}\text { Hotel Restaurnat } \\
\text { Le Relax }\end{array}$ & 35 rooms \\
\hline
\end{tabular}

The second route (Figure 4) leads from Slovakia (Žilina) to Hamburg (Hamburg), with 145 truck parks available, but the driver can take regular weekly rest for only 15 of them (Table 2). Most of the truck parks on the given route providing accommodation are in this case in Poland, namely 9 out of 15 and the smallest in the Slovak Republic, but in this case it should be noted 
that the transport route within SR is only $39 \mathrm{~km}$ out of a total of $1048 \mathrm{~km}$. Information on the accommodation capacity was available in 8 cases, of which 4 are less than 20 rooms and only one accommodation has more than 40 rooms.

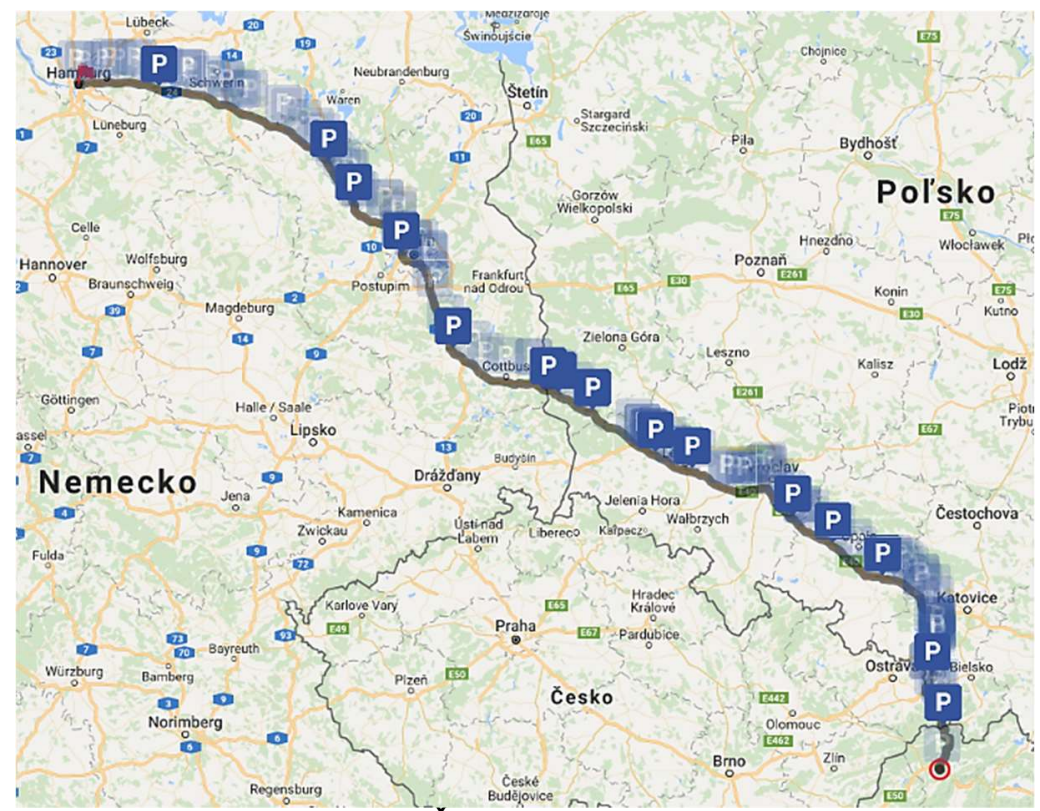

Fig. 4. Route 2 SK (Žilina)-DE (Hamburg) - 1048 km

Table 2

Possibilities of regular weekly rest on the route Žilina (SK)-Hamburg (DE)

\begin{tabular}{|c|c|c|c|c|}
\hline Number & $\begin{array}{l}\text { Parking for trucks } \\
\text { with accommodation }\end{array}$ & Country & Accommodation & $\begin{array}{l}\text { Accommodation } \\
\text { capacity }\end{array}$ \\
\hline 1. & $\begin{array}{l}\text { Slovnaft Svrčinovec Gas Station, } 02312 \\
\text { Svrčinovec-Purašovci }\end{array}$ & SK & Hotel Paris & not indicated \\
\hline 2. & Babilon, 938 Hażlach & $\mathrm{PL}$ & Restauracja Babilon & 7 rooms (17 beds) \\
\hline 3. & MOP Wysoka A4/E40, Góra Św. Anny & $\mathrm{PL}$ & $x$ & not indicated \\
\hline 4. & $\begin{array}{l}\text { Młyński Staw, A4/E40, Rzędziwojowice, } \\
\text { Niemodlin }\end{array}$ & PL & HOTEL Comfort Express & 12 beds \\
\hline 5. & $\begin{array}{l}\text { MOP Oleśnica Mała, E40 72, 55-200 } \\
\text { Oleśnica Mała }\end{array}$ & $\mathrm{PL}$ & Hotel MOP Oleśnica Mała & 10 rooms \\
\hline 6. & Hotel Dworek, 59-241 Lubień & $\mathrm{PL}$ & Hotel Dworek & 30 rooms $(60$ beds) \\
\hline 7. & Milenium, Jadwisin 24, 59-516, & $\mathrm{PL}$ & $\mathrm{x}$ & not indicated \\
\hline 8. & Circle K Iłowa 68-120 Czerna & $\mathrm{PL}$ & $\mathrm{x}$ & not indicated \\
\hline 9. & $\begin{array}{l}\text { Stacja Paliw Orlen Trzebiel, 68-212 } \\
\text { Jędrzychowiczki }\end{array}$ & PL & Motel INTERTANK & 43 beds \\
\hline 10. & $\begin{array}{l}\text { Stacja Paliw Speed, Olszyna 2, } \\
\text { 68-212 Olszyna, Pol'sko }\end{array}$ & PL & $\mathrm{x}$ & not indicated \\
\hline 11. & $\begin{array}{l}\text { Rasthof Berstetal, A13/E36/E55, Kaden, } \\
\text { Luckau }\end{array}$ & $\mathrm{DE}$ & $\mathrm{x}$ & not indicated \\
\hline 12. & $\begin{array}{l}\text { Raststätte Avus, Nordkurve, } \\
\text { Charlottenburg, Berlin }\end{array}$ & DE & Avus Raststätte Motel & $\begin{array}{l}46 \text { rooms } \\
\text { ( } 79 \text { beds }+2 \\
\text { apartments) }\end{array}$ \\
\hline 13. & $\begin{array}{l}\text { Pension - Truck-Center, Gewerbepark 5, } \\
16833 \text { Fehrbellin }\end{array}$ & DE & Pension Truck-Center & 6 rooms (10 beds) \\
\hline 14. & $\begin{array}{l}\text { Shell Autohof Herzsprung, Steinstraße 9, } \\
16909 \text { Wittstock/Dosse }\end{array}$ & DE & Autohof Herzsprung & not indicated \\
\hline 15. & $\begin{array}{l}\text { Raststätte Gudow Nord, A24 } 23899 \\
\text { Gudow }\end{array}$ & DE & $\begin{array}{l}\text { Autobahnhotel Gudow } \\
\text { Nord }\end{array}$ & $\begin{array}{l}28 \text { rooms } \\
\text { (46 beds) }\end{array}$ \\
\hline
\end{tabular}

The last route analyzed (Figure 5) was the route leading from SR (Žilina) to Italy (Livorno). There are 113 truck parks on this route, 15 of them with accommodation. The route includes three states - Slovakia, Austria and Italy, with 7 truck parks in Austria (Table 3) and 8 in Italy ( 3 truck parks are next to each other, i.e. the same accommodation in all three). The capacity of accommodation facilities was found in 13 cases where the best possibilities provide truck parks in Italy, which mostly have a capacity of more than 40 rooms. 


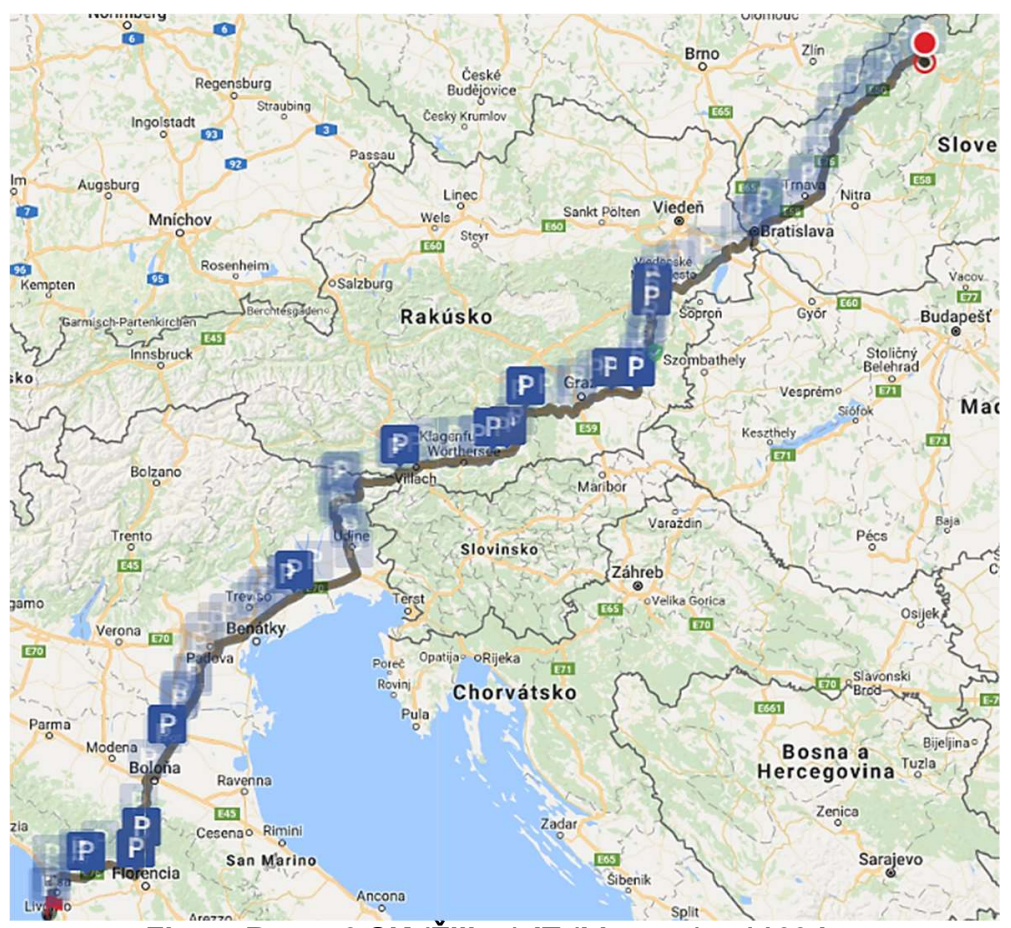

Fig. 5. Route 3 SK (Žilina)-IT (Livorno) - 1163 km

Table 3

Possibilities of regular weekly rest on the route Žilina (SK)-Livorno (IT)

\begin{tabular}{|c|c|c|c|c|}
\hline Number & $\begin{array}{l}\text { Parking for trucks } \\
\text { with accommodation }\end{array}$ & Country & Accommodation & $\begin{array}{l}\text { Accommodation } \\
\text { capacity }\end{array}$ \\
\hline 1. & Gasthof Pichler, Bundesstraße 4, 2840 Grimmenstein & AT & Gasthof Pichler & 24 beds \\
\hline 2. & Oldtimer Raststätte, Süd Autobahn, Zöbern & AT & $\begin{array}{l}\text { Oldtimer } \\
\text { Raststätte }\end{array}$ & $\begin{array}{l}20 \text { rooms } \\
\text { (40 beds) }\end{array}$ \\
\hline 3. & Autohof IIz, Hainfeld 56, A $8262 \mathrm{IIz}$ & AT & Welog Rast IIz & 4 rooms \\
\hline 4. & $\begin{array}{l}\text { Rasthaus Dokl Hofstätten an der Raab, Hofstätten } \\
113,8200\end{array}$ & AT & Rasthaus Dokl & $\begin{array}{l}20 \text { rooms } \\
\text { (40 beds) }\end{array}$ \\
\hline 5. & $\begin{array}{l}\text { Raststätte Pack Preitenegg, Süd Autobahn, } \\
\text { Preitenegg }\end{array}$ & AT & $\begin{array}{l}\text { Motorhotel } \\
\text { Oldtimer }\end{array}$ & $\begin{array}{l}16 \text { rooms } \\
\text { (32 beds) }\end{array}$ \\
\hline 6. & $\begin{array}{l}\text { Mochoritsch Griffen-Rast Griffen, Gewerbestraße 11, } \\
9112 \text { Griffen }\end{array}$ & AT & $x$ & not indicated \\
\hline 7. & Raststätte Völkermarkt, A-9100 Völkermarkt & AT & $\begin{array}{l}\text { Hotel } \\
\text { Rosenberger } \\
\text { Autobahn- } \\
\text { Restaurant \& } \\
\text { Motorhotel } \\
\end{array}$ & $\begin{array}{l}42 \text { rooms } \\
\text { ( } 84 \text { beds) }\end{array}$ \\
\hline 8. & $\begin{array}{l}\text { Raststätte Dreiländerecke Süd, Süd Autobahn, } \\
\text { Arnoldstein }\end{array}$ & IT & $\begin{array}{l}\text { Raststätte } \\
\text { Dreiländerecke } \\
\text { Süd }\end{array}$ & 90 beds \\
\hline 9. & $\begin{array}{l}\text { Albergo Ristorante da Gigi, Via Fosson,30, Santo } \\
\text { Stino di Livenza }\end{array}$ & IT & $\begin{array}{l}\text { Albergo Ristorante } \\
\text { da Gigi }\end{array}$ & $\begin{array}{l}29 \text { rooms } \\
\text { (56 beds) }\end{array}$ \\
\hline 10. & $\begin{array}{l}\text { Albergo Melograno, Strada Provinciale 20, } 40018 \text { San } \\
\text { Pietro in Casale BO }\end{array}$ & IT & $x$ & not indicated \\
\hline 11. & $\begin{array}{l}\text { Ristorante da Marisa, Viale del Lago, Barberino di } \\
\text { Mugello }\end{array}$ & IT & Hotel Barberino & 78 rooms \\
\hline 12. & $\begin{array}{l}\text { Ristorante da Emma, Viale del Lago, Barberino di } \\
\text { Mugello }\end{array}$ & IT & Hotel Barberino & 78 rooms \\
\hline 13. & $\begin{array}{l}\text { Hotel Barberino, Via del Lago, 17, } 50031 \text { Barberino di } \\
\text { Mugello Florenz }\end{array}$ & IT & Hotel Barberino & 78 rooms \\
\hline 14. & Firenze Nord, A1 / A11 & IT & Hotel The Gate & 157 rooms \\
\hline 15. & Ristorante Orcino, Via delle Cerbaie, Altopascio & IT & Hotel Le Cerbaie & 64 rooms \\
\hline
\end{tabular}

Table 4 shows the comparison of the individual routes with regard to the number of truck parks, while on the Žilina-Lyon route there are $8 \%$ truck parks with accommodation of the total number of truck parks on the route. The Žilina-Hamburg route there are 10\% truck parks and for the Žilina-Livorno route the parks with accommodation facilities represent $13 \%$. 
Table 4

Comparison of individual routes with respect to the number of truck parks

\begin{tabular}{|l|c|c|c|}
\hline \multicolumn{1}{|c|}{ Route } & Total route & Parking for trucks & Parking for trucks with accommodation \\
\hline Žilina-Lyon & $1449 \mathrm{~km}$ & 201 & 16 \\
\hline Žilina-Hamburg & $1048 \mathrm{~km}$ & 145 & 15 \\
\hline Žilina-Livorno & $1163 \mathrm{~km}$ & 113 & 15 \\
\hline
\end{tabular}

\section{CONCLUSION}

With regard to processing analysis of the truck parks that provide driver accommodation, it can be confirmed that truck parks generally do not have motels or hotels near them. Many accommodation facilities are located within a city where freight parking is not allowed, so the drivers would have to get to the nearest accommodation facility somehow. There is also a risk of transported goods if the vehicle is parked in an unsecured truck park. In case the truck parks are not guarded there is a risk of possible damage to the transported goods or theft of not only the goods but also the whole vehicle. When planning a transport, it is also necessary to take into account, in addition to the provision of a suitable truck parks providing accommodation for the driver, the current capacity as some of them have a relatively low number of rooms.

A ban on regular weekly rest in the vehicle can interfere with some important transport routes and may also have an impact on transport companies operating on the West European market and using cabotage and longer periods of time during which the driver operates outside the base of the enterprise.

\section{ACKNOWLEDGEMENTS}

The contribution was elaborated with the support of the Ministry of Education of the Slovak Republic VEGA no. 1/0566/18 KONECNY, V.: Výskum vplyvu ponuky a kvality dopravných služieb na konkurencieschopnost' a udržatel'nost' dopytu po verejnej osobnej doprave.

\section{REFERENCES}

Lubanski, N. (2000). Moving Closer together - Trade union europeanisation in the construction sector. Transfer 1, pp. 103-109.

CEMT (2002). Le Dumping Social dans l'Espace Couvert par la CEMT. Application au Cas du Transport Routier de Marchandises., Paris: OCDE.

Poliak, M., Gnap, J. (2015). Práca vodičov nákladných automobilov a autobusov a používanie tachografov. Vydavatel'stvo EDIS, Žilina.

Poliak, M., Poliaková, A. (2015) Relation of social legislation in road transport on driver's work quality. In: Tools of transport telematics. Wroclaw, pp. 300-310.

Ayala, D., Wolfson, O., Xu, B., Dasgupta, B., Lin, J. (2010). Pricing of parking for congestion reduction, In: Proceedings of Sigspatial/GIS. Chicago, pp. 43-51.

Newman, P., Kenworthy, J. (1999). Overcoming automobile dependence. In Sustainability and cities, Washington: D.C., pp. 442.

Rotondo, E. (2013). The legal effect of EU Regulations. Computer Law \& Security Review, 29(4), pp. 437-445.

Domonkos, T., Ostrihon, F., Sikulova, I., Siranova, M. (2017). Analyzing the relevance of the MIP scoreboard's indicators. National Institute Economic Review, 239(1), pp. R32 - R52.

Poliak, M. (2007). Dokladovanie pracovného režimu vodičov cestnej dopravy. In: Kilometer informačný spravodajca Združenia cestných dopravcov Slovenskej republiky. 15(5), pp. 20-21.

Drozdziel, P., Piasecki, S. (1995). Study of the medthod of assessing the economic efficiency of exploitation cars in a transport company. In: Folia Societatis Scientarium Lublinensis. Lublin, pp. 60-66. 